\title{
Perceived Authenticity of California Missions
}

\author{
Daniel Levi \\ PhD; Professor, Psychology and Child Development Department, Cal Poly.
}

\begin{abstract}
This article discusses the difference between the concepts of authenticity and perceived authenticity, and how they relate to tourism and historic presentation. Three Central Coast Missions provide examples of how these two concepts diverge when religious and tourist-related uses conflict, and the implications for planning.
\end{abstract}

A uthenticity is an important concept in both historic preservation and in tourism. In historic preservation, authenticity is a criterion for the selection, maintenance, and preservation of historic places (Wells, 2010). For tourists, authenticity is a criterion for the selection and evaluation of the cultural tourism sites they visit (Yeoman, Brass \& McMahon-Beattie, 2006). However, authenticity is an elusive concept than can be difficult to define (Timothy \& Prideauz, 2004). Because of the elusiveness of actual authenticity, perceived authenticity is the study of the factors that influence why people experience a place as authentic. The California Missions provide a good example of the challenges of determining both the authenticity and perceived authenticity of a place.

The Central Coast of California has several historic Missions. Although many of the California Missions fell into decay during the 1800s, they were revitalized during the Mission revival era in the 1920s and 30s (Johnson, 1979). The Missions are still significant today for several reasons. They are important religious sites that support local Catholic parishes, historic sites that are studied by school children throughout the state, and tourist sites that attract thousands of visitors. Because the Missions are valuable for religious, historic, and tourist reasons, preserving these places and maintaining their uses are important for the social and cultural vitality of the region.

The California Missions are valued for religious, historic, and tourism reasons; however, these three goals can create conflicts among the uses (Shackley, 2001). The preservation of a historic site can conflict with its use by the religious community and by tourists. If no one visited a historic site, it would be easier to preserve; but use by the local community and visits by tourists provide the social and financial support for its maintenance (Olsen, 2006). The local religious community may want to modify or modernize a site to support their use, which can conflict with a focus on historic preservation. For example, changes like modern lighting and plumbing may make a place more usable; or it may be enlarged and modified to better support religious activities; or it may be redesigned to reflect modern aesthetic preferences, not necessarily with historic preservation as a major goal.
There are also conflicts between tourism and the religious community (Bremmer, 2006). Tourists can disrupt religious activities, and historic religious sites develop various strategies for managing these intrusions. However, the local religious community does not reject tourism of the Missions because they are proud of their heritage and recognize that tourism provides an economic incentive for preservation.

\section{Authenticity and Perceived Authenticity}

The authenticity of historic places such as the California Missions plays a significant role in both historic preservation and tourism. For historic preservationists, authenticity is used to make decisions about which places should be preserved and what modifications are acceptable. For tourists, authenticityor perceived authenticity-is important in their decisions too. Tourists want to visit authentic sites, but they may not have the information or background to know whether a place is actually authentic (Poria, Butler\& Airey, 2003).

Historic preservation relies upon multiple definitions of authenticity to evaluate places (Wells, 2010). The most common definition focuses on the physical dimensions-whether the historic structures and artifacts are intact or have been changed over time. Authenticity also relates to whether the historic uses or functions continue (McKercher \& du Cros, 2002). For example, when a historic church is converted into a restaurant, it no longer has the same authentic value. The meaning of the place to the local community is related to its authenticity (Levi \& Kocher, 2012). Historic events may cause a place to be viewed as authentic, but this history must be remembered by the community for the place to still be considered historic.

Perceived authenticity relates to the characteristics both of the site and of the visitors (Macleod, 2006). Like historic authenticity, perceived authenticity relates to the physical characteristics of the place and its current social uses. The way the place is interpreted for visitors influences its perceived authenticity (Bremmer, 2000). Interpretation tells visitors what they should focus on and what the site's meaning is. Is this primarily a historic, tourist, or religious site? The context of the site also im- 
pacts perceived authenticity. The California Missions were rural, agricultural places, but today many of them exist in urban environments that change one's perception of them.

The characteristics of the visitors also impact the perceived authenticity of historic places. The social and cultural background of visitors influences their ability to read or interpret these places (Poria, Butler \& Airey, 2003). For example, non-Christian visitors may have a difficult time interpreting the symbols and meaning of what they are seeing at the Missions. Knowledge of the site's history affects people's evaluations of it. People are not always able to tell whether a place is historic or modern construction (Levi, 2005). Although the Mission San Luis Obispo chapel says "1776" above the door, that is not the date when the current chapel was built. Tourists also vary on the motivation for their visit (Nolan \& Nolan, 1992). The perception of a Mission depends on whether the purpose is visiting the tourist sites in a city versus making a religious pilgrimage to see the Missions. Finally, perceived authenticity is influenced by a person's experience when visiting the site. Visiting Mission San Luis Obispo is a different experience for someone who arrives during a "Concerts in the Plaza" event, when a large crowd gathers to enjoy amplified live music in the plaza adjacent to the Mission buildings.

\section{Historic Authenticity of the California Missions}

It is not always clear what is historically authentic, so we should not be surprised that people vary in their evaluations of perceived authenticity. The recent history of three Central Coast Missions has impacted their authenticity. Mission San Miguel has intact historic structures, but maintenance issues limit visitors and use by the local parish. Mission San Luis Obispo has had many modifications over the years to support use by the parish. Mission La Purisima is a Works Progress Administration (WPA) reconstruction of a destroyed Mission, and it is not a religious place from the perspective of the Catholic Church.

The following descriptions were developed to describe the authenticity and experience of visiting these Missions for tourists:

Mission San Luis Obispo is in downtown SLO. The Mission has been extensively rebuilt and modified over the years with funds from the parish and the local business community. The main chapel was constructed in the 1930s using concrete in a "historic" style. The interior of the chapel was redesigned 10 years ago in a non-historic style. There is a gift shop and museum. The parish is active and religious services occur regularly. The plaza in front of the Mission was built by the City in the 1970 s and is used for community events.

Mission San Miguel, located within the town of San Miguel, is one of the least modified of the California Missions. It is located within the town of San Miguel. Because of nearby railroad tracks and an earthquake a decade ago, the Mission is in fragile condition and substantial maintenance work is occurring. Many parts of the Mission are not open to the public because

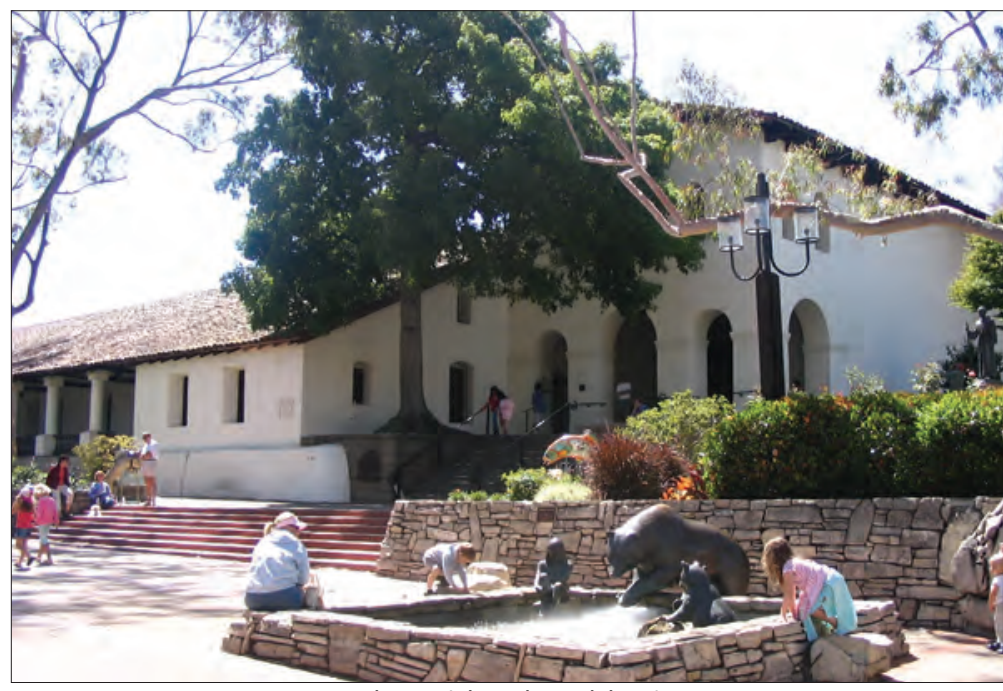

Figure 1: Mission San Luis Obispo. (photo by V. del Rio)

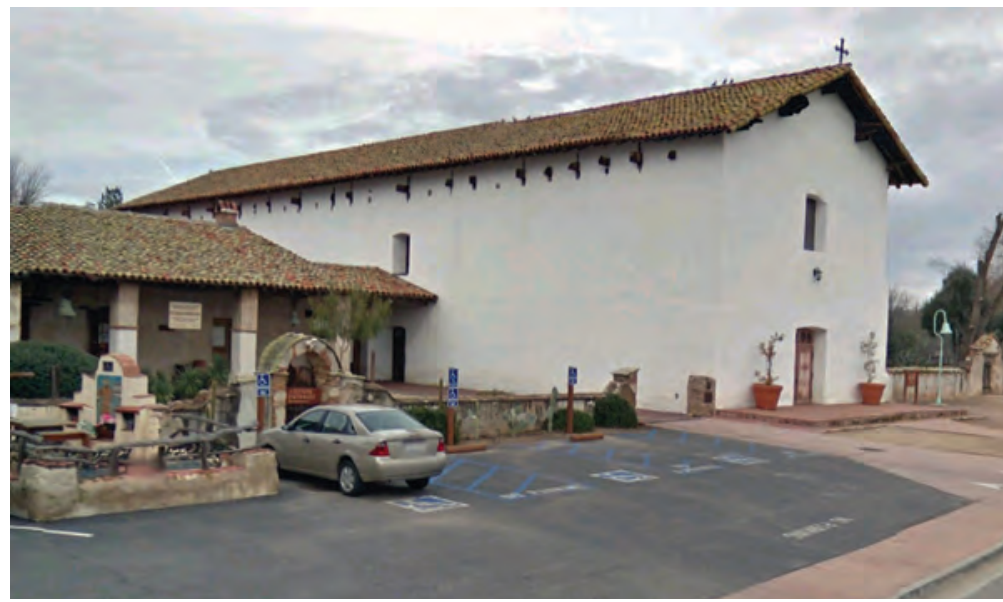

Figure 2: Mission San Miguel. (photo from Google Earth)

Figure 3: Mission La Purisima. (photo by Larry Myhre; www.flickr.com)

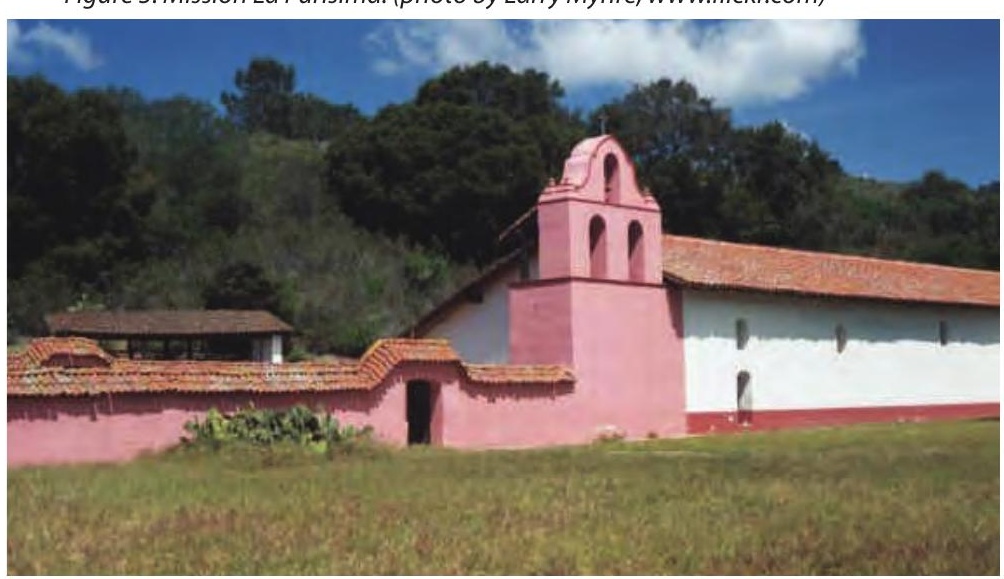


of the fragile condition of the structures and other uses. The parish uses some of the historic buildings, but most parish activities occur in a modern building adjacent to the site. There is a gift shop and museum.

Mission La Purisima is a California Mission reconstruction, started as a WPA project in the 1930s. It is near the site of a historic Mission that was destroyed by an earthquake in the $1800 \mathrm{~s}$. The reconstruction used historically appropriate materials and methods. The Mission site is in a rural area and includes agricultural fields, pasturelands, farm buildings, Native American housing, and other structures that would have existed at a Mission in the 1700s. It is currently operated as a State Historic Park.

\section{Studying Perceived Authenticity}

It is difficult to determine which of these Missions is most historically authentic. Perceived authenticity and the tourist experience depend on the characteristics of the site, the background and knowledge of the visitors, and their experience visiting the site. In order to explore the perceived authenticity of these places, my students in several Cal Poly classes have conducted projects and discussions.

Student site visits. Over the course of several years, I taught an Honors class on historic sacred places that was a section of my Environmental Psychology class. The students became fairly sophisticated evaluators of the authenticity of historic places and historic preservation issues related to the Missions. They visited three Central Coast Missions, made ratings about their experiences there, and wrote an evaluation of the Missions' perceived historic authenticity and sacredness.

The students rated Mission San Miguel as the most historically authentic, followed by Mission San Luis Obispo and then Mission La Purisima. Mission San Miguel was viewed as having historic buildings, but limited access and maintenance issues disrupted one's experience of the place. Mission San Luis Obispo was viewed as authentic because it is a functioning parish with close ties to the community, but there have been many modifications to the historic structures. Mission La Purisima had the most historic feel, but it was considered an inauthentic place because of when and why it was constructed.

One of the interesting aspects of this project was to see how the evaluations of these sites depended on the characteristics of the students and their experience when visiting the site. Although these students were very knowledgeable about design and historic preservation issues because of the class they were taking, they differed due to their religious backgrounds. Some of the students focused on the architectural characteristics of the place, while others focused on the religious history and current use of the place. Their experience of the sites varied by what happened to them on the day they were visiting. The experience of Mission La Purisima depended on whether there were few other visitors to this peaceful rural setting, or they were sharing the place with busloads of school children. Dur- ing some years, visitors to Mission San Miguel were confronted with warning signs related to the maintenance caused by the earthquake damage, while other visits allowed the students to observe the chapel being used by the local parish.

Tourism survey. One of the focuses of the study of perceived authenticity is how it relates to the experience of tourists. The descriptions of the three Missions presented here were given to students in an Environmental Psychology class and in a graduate City and Regional Planning class. They were asked:

"You have out-of-town visitors from the East Coast who want to see one of the California Missions. You want them to have an 'authentic' experience of visiting a Mission. Which of the three Missions described best captures the California Mission experience? Explain your answer."

Mission La Purisma was selected by $52 \%$ of the students because its rural setting captures the historic lifestyle of the Missions. Mission San Miguel was selected by $34 \%$ of the students because it has the most historically authentic buildings. Mission San Luis Obispo was selected by $14 \%$ of the students because although it has been substantially modified, it is still an active religious place that is used by the community.

\section{Conclusions}

Perceived authenticity is important because it relates to tourism, and therefore social and financial support for historic preservation of the Missions. It is influenced by the historic characteristics of the place, the background characteristics of the visitors, and their experience visiting the place. The continued religious use of the Missions increases their perceived authenticity and helps to preserve their meaning. Interpretation of the site also matters. The California Missions are advertised as cultural tourist sites and are often interpreted as historic sites. A stronger interpretative focus on the religious meaning of these places may help to reduce the conflicts between tourism and the local religious community and encourage respect for the historic and spiritual values.

This student research demonstrates the difference between the concepts of authenticity and perceived authenticity, and how these concepts relate to tourism. Historic preservation strives for authenticity, while the tourist industry wants perceived authenticity. The Central Coast Missions provide an example of where these two searches diverge. To historic preservationists, Mission San Miguel is a historically authentic place that needs protection and maintenance to preserve its damaged structures. For tourists, Mission La Purisima provides an authentic experience that allows them to see what Mission life might have been like.

Tourists are seeking authentic experiences to better understand the history and culture of a region. This search for authentic experiences can be satisfied in a variety of ways. Tourists can visit the authentic structures of Mission San Miguel, or 
experience the life of the Missions at Mission La Purisima, or see how active community involvement has made Mission San Luis Obispo a focal point for the community. All of these are authentic experiences that are an important part of cultural tourism, and the different Missions provide alternative approaches for obtaining these experiences.

\section{References}

Bremer, T. 2000. Tourists and religion at Temple Square and Mission San Juan Capistrano. The Journal of American Folklore, 113(450), 422-435.

2006. Sacred spaces and tourist places. In D. Timothy \& D. Olsen (Eds.), Tourism, religion and spiritual journeys (pp. 2535). New York: Routledge.

Johnson, P. 197). The California Missions. Menlo Park: Sunset Books.

Levi, D. 2005. Does history matter? Perceptions and attitudes toward fake historic architecture and historic preservation. Journal of Architectural and Planning Research, 22(2), 148-159.

Levi, D. \& Kocher, S. 2001. Perception of sacredness at heritage religious sites. Environment and Behavior, DOI: $10.1177 / 0013916512445803$.

Macleod, N. 2006. Cultural tourism: Aspects of authenticity and commodification. In M. Smith and M. Robinson (Eds.), Cultural tourism in a changing world (pp. 177-190). Clevedon: Channel View Publication.
McKercher, B. \& du Cros, H. 2002. Cultural tourism: The partnership between tourism and cultural heritage management. New York: Haworth Hospitality Press.

Nolan, M. \& Nolan, S. 1992. Religious sites as tourism attractions in Europe. Annals of Tourism Research, 19, 68-78.

Olsen, D. 2006. Management issues for religious heritage attractions. In D. Timothy \& D. Olsen (Eds.), Tourism, religion and spiritual journeys (pp. 104-118). New York: Routledge.

Poria, Y., Butler, R. \& Airey, D. 2003. Tourism, religion and religiosity: A holy mess. Current Issues in Tourism, 6(4), 340-363.

Shackley, M. 2001. Managing sacred sites. Padstow, UK: Thomson.

Timothy, D. \& Prideauz, B. 2004. Issues in heritage and culture in the Asia Pacific region. Asia Pacific Journal of Tourism Research, 9(3), 213-223.

Wells, J. 2010 Authenticity is more than one dimension. Forum Journal of the National Trust for Historic Preservation, 24(3), 36-40.

Yeoman, I., Brass, D. \& McMahon-Beattie, U. 2006. Current issues in tourism: The authentic tourist. Tourism Management, 28(4), 1128-1138. 